\title{
SMOOTHING BEHAVIOR OF FIRMS IN TIMES OF CRISIS: EMPIRICAL EVIDENCE FROM THE SPANISH ECONOMIC ENVIRONMENT
}

\author{
Alina Beattrice Vladu ${ }^{l}$
}

\begin{abstract}
The main goal of this particular research was to assess whether the listed companies in Spain behave differently in bad economic times versus good economic times. In this regard, the smoothing behavior of Spanish listed firms was examined. The results obtained document for the 2008-2009 financial crisis period a decrease in income smoothing activities. Results, implications and scope for future research are discussed.
\end{abstract}

Keywords: income smoothing; financial crisis; earnings management

JEL Codes: M41, M40

\section{Introduction}

The financial reporting is relevant when it has the potential to influence the decisions in the economic environment. The focus of this paper is converging to this demarche, since it analyzes the quality of financial reporting using as proxy the existence of income smoothing.

In year 1953, Hepworth asserted that at the beginning of the $20^{\text {th }}$ century the attention of the investors, financial analysts, employees and general public was on the balance sheet. Today, in the light of previous accounting scandals, the attention of all the above is on earnings and cash flow. Even if it did not had such a big success from the beginning, compared with the balance sheet, the income statement succeed not only to gain everybody's attention, but also to be an extremely important tool for assessing the quality of earnings.

In seeking of the wholly fairness, accounting information users in nowadays, tend to rely on income statement primarily. Generating information about companies and disclosing the success of their operations, the income statement can be the perfect tool for above assessment, if it would not be often affected by accrual-based earnings management.

In their determination to present a strong image for their companies, managers sometimes choose carefully the methods that are helping them to disclose desired information in regard of their companies' performance. In some situations, they use the opportunity to alter income figures using the changing in accounting methods. The result will be an increase or decrease in the income figures that on the long run will provide a smooth trend for the income, offering a strong and stable image for the company (Dye, 1988). The multiple incentives of income smoothing can be a good motivation for Spanish companies, especially in times of financial crisis, when earnings usually do not have a smooth pattern.

This paper explores the smoothing behavior of firms in times of crisis, using a sample of Spanish listed companies. The view of smoothing behavior assessed is approached in terms of opportunism as in the conceits of Healy (1985); Watts and Zimmerman (1990); Fudenberg and Tirole (1995), DeFond and Park (1997); Healy and Wahlen (1999).

In this respect, the information provided in financial statements prepared in Spanish economic environment analysis is considered timely and relevant. Even if the results are focused on a single country, they can be extended to others countries having similar characteristics as Spain.

\footnotetext{
${ }^{1}$ Babeş-Bolyai University, Cluj-Napoca, Romania and Pompeu Fabra University, Barcelona, Spain, e-mail: beattrice.vladu@econ.ubbcluj.ro; e-mail: beattrice.vladu@upf.edu
} 
This study can extend the literature in several ways. First, it extends the assessment of smoothing behavior of firms in bad financial times. Second, extends the literature by focusing on earnings management in countries from Euro Continental accounting model (Zeghal et al., 2011), where very few studies were conducted comparing to Anglo-American world. Third, this study offers more empirical evidence that supports the managerial propensity to smooth earnings (Buckmaster, 2001) especially in code-law countries with low investors protection rights and low enforcement (Leuz et al., 2003). Fourth, this study converges and extends the literature that sustains the pervasiveness of income smoothing (Levitt, 1998; Graham et al., 2005). Fifth, the findings offer insights into the ongoing debate on the role of adjusted or smoothed earnings (Bradshaw and Sloan, 2002; Bhattacharya et al., 2003; Lougee and Marquardt, 2004; Choi et al., 2005).

The reminder of the paper is organized as follows: second section introduces background and develops the research hypothesis; section three discusses the research design; section four presents the empirical results and discussions while latter section concludes and presents the limitations of the study and the scope for future research.

\section{State of the art and research hypothesis development}

Income smoothing literature had its genesis in three important studies. First, the study conducted by Gordon (1964). In this particular study income smoothing is conceptualize as being a rational behavior of managers based on three items: the maximization of their own utility, maximization of the firm value and shareholder satisfaction and the maximization of stock price. In his framework, Gordon (1964) asserted that the market is inefficient and as a main result, income smoothing activities cannot be explored only with great difficulty. A second study that is part of the theoretical foundation of income smoothing literature is the one conducted by Watts and Zimmerman (1978). In their framework, the market is efficient and as a result, income smoothing behavior can be detected. Third, the study conducted by Lambert (1984) can be mentioned, who thoroughly explained the smoothing behaviors of firms using the agency theory.

According to the literature, earnings smoothing is a special case of earnings management, where managers smooth out inter-temporal volatility in reported earnings with the scope of disclosing a stable earnings stream, with less variations as possible (Biedleman, 1973; Koch, 1981; Fudenberg and Tirole, 1995).

Classified, as being informative or opportunistic, the trend assessed in this paper is the latter one.

Many reasons can be depicted for managers acting opportunistically, among them various studies published in mainstream accounting journals document the bonus schemes, jobs security, better relations with stakeholders, tax advantages, lower cost of capital as the most cited (Healy, 1985; Moses, 1987; Trueman and Titman, 1988; Holthausen et al., 1995; DeAngelo, 1988; Dechow and Sloan, 1991; Fudenberg and Tirole, 1995; DeFond and Park, 1997).

The impact of income smoothing is also extensively documented in the literature. In this regards, several effects are documented as: smoothing companies experience higher bid-ask spreads and lower trading volumes (LaFond et al., 2007); countries with smoothed earnings have a higher cost of capital (Bhattacharya et al., 2003); smoother firms have a lower ten-year annualized return and higher cumulative average of abnormal return comparing with non-smoothers (Michelson et al. 1995; Michelson et al. 2000); smothers market response to earnings is four times as large as that for non-smoother firms (Wang and Williams, 1994); the value for the smoothers decrease with the magnitude of accruals (Huang et al., 2009).

When it comes to the methods of detecting the smoothing behavior, several methods are approached in the literature: assessing the variations in net income as a result of accounting changes (Herrman and Inou, 1996); assessing the variations of ordinary income (Ronen and Sadan, 1975); assessing the variations in sales comparing to variations in net income (Imhoff, 1977; Eckel, 1981); assessing the magnitude of discretionary accruals (Shaw, 2003). 
The measures for assessing the smoothing behavior of firms used in this particular study are the ones employed by Leuz et al. (2003) consisting in assessing the variation in net income, cash flow and total accruals. Those two measures were chosen based on their potential of assessing the smoothing behavior (Leuz et al., 2003).

Further, studies like the ones conducted by: Leuz et al., 2003; Daske et al., 2006; Han et al., 2010; Zeghal et al., 2011; documented that earnings management magnitude is higher on average in code-law countries with low investors' protection rights than in common-law countries with high investor protection rights. In this respect, cultural and institutional factors may explain different patterns of discretion in different countries. La Porta et al. (1998) show that different types of legislation in particular countries result in different types of enforcement. In a code-law country within "French group" like Spain, shareholder protection and law enforcement have traditionally been lower than in other code-law countries (La Porta, et al., 1998; Leuz et al., 2003). Therefore the mechanisms to achieve appropriate enforcement vary under different types of code or common-law environments (Leuz et al., 2003; Navarro-Garcia and Bastida, 2010).To summarize the above conceits, when dealing with a jurisdiction as Spain where there are insufficient incentives to present transparent financial reporting (Navarro-Garcia and Bastida, 2010).

Assessing the impact of financial crisis on earning management, previous studies conducted in the literature documented an inverse relationship. In this respect, macroeconomic conditions have the potential to impact earnings management activities.

The study conducted by Filip and Raffournier (2012) documented that earnings management has significantly decreased in the crisis years and that this trend is confirmed in most of the countries in Europe. The main argument of the authors is related to the fact that is possible for managers to have less incentive to manipulate earnings in crisis periods due to a higher market tolerance for poor performance. Strobl (2013) asserted also that managers are more likely to engage in opportunistic behavior during an economic boom as opposed to a recession period. Cohen and Zarowin (2007) and Ahmad-Zaluki et al. (2011) documented empirically similar results with Strobl (2013).

According to previous results documented in the literature the financial crisis can have a negative impact or positive impact on the manipulators behavior. Until this moment it is unclear whether financial crisis should increase the incentives for firms to engage in more earnings management activity of just to report unbiased financial figures. Since there are more studies documenting a potential decrease in the smoothing behavior of firms in times of crisis, the research hypothesis tested in this paper is the following:

H: The smoothing behavior of Spanish listed firms changes in bad financial periods. In particular, the income smoothing decreases in times of bad financial periods.

\section{Research design}

This particular section explores the research design employed in this empirical paper. In order to test for the abnormal behavior via income smoothing in times of crisis both the accruals quality literature and also the work of scholars examining the income smoothing area was assessed.

As indicators for income smoothing two measures taken by Leuz et al. (2003) were used. Those measures were tested also in the empirical study conducted by Filip and Raffournier (2012) being measures that are focusing on the internal choices of managers.

In this respect, the first measure (e.g. IS1) is defined as the standard deviation of cash flow from operations divided by standard deviation of net income. Both are scaled by lagged total assets from previous year to reduce heteroskedasticity. If the variability of net income is less than the variability of cash flow from operations, the smoothing behavior via opportunistic purposes can be documented. The standard deviation of net income is showing the variability of earnings. High values of this first measure are documenting the existence of income smoothing (Leuz et al., 2003). 
The second measure (e.g. IS 2) is taken also from Leuz et al. (2003) and comprises both the assessment of total accruals and cash flow from operations. This measure consists in testing for income smoothing behavior using the Spearman correlation between variations in accruals and variations in cash flow from operations. Both are scaled by lagged total assets from previous year to reduce heteroskedasticity.

According to Dechow (1994), the correlation between changes in accruals and changes in cash flow should be negative. If accruals are manipulated by managers with the purpose to smooth income, the absolute value of their correlation with cash flow from operations should be high.

In order to be able to use this second measure, first the total accruals must be calculated. Taking into account the advantages of cash flow approach comparing with balance sheet approach, the method used in this paper to calculate total accruals is the cash flow statement approach. In this respect the total accruals are calculated as the difference between the net income and the cash flow from operations. A high negative correlation between the indicators comprised in the second measure can be interpreted as a sign of income smoothing (Barth et al., 2008; Lang et al., 2006; Ball and Shivakumar, 2005; Filip and Raffournier, 2012). Similar to Filip and Raffournier (2012), the Spearman coefficient was multiplied by -1 so that higher IS 2 scores reflect higher level of income smoothing. That was done for the consistency of presentation and interpretation.

\section{Sample}

Our sample comprises all non-financial listed companies on Madrid Stock Exchange, tier I and tier II. When the information disclosed on the Madrid Stock Exchange (www.bolsamadrid.es) was incomplete, the missing data was collected manually from the following internet site that discloses the annual reports of listed companies in Spain: http://www.abertis.com/informeanual/var/ lang/es/idm/119/ano/2005/ord/1. The manually collected data was used to calculate using the indirect method the cash flow from operations for period 2005-2007. For period 2008-2012, information's regarding the cash flow from operations was disclosed on Madrid Stock Exchange.

Our sample comprises 8 years (2005-2012), and the companies assessed were commercial and industrial. This decision was taken based on the fact that previous indicators of income smoothing are developed for this kind of companies. Even if Capkun et al. (2011) documented more earnings management in the first year of adoption of IFRS, based on the fact that managers may use the discretion allowed under IFRS 1 to manipulate earnings, this year was part of this analysis.

The initial sample comprises 274 firms for the period 2005-2012, from whom 66 banks and financial institutions were excluded. Also, observations with unavailable accounting reduce the sample leaving the final sample with 1044 final number observations. Outliners in each industry were excluded. The sample composition is presented in Table no. 1.

Table no. 1

The sample

\begin{tabular}{|l|c|}
\hline Number of firms listed on MSE (2005 - 2012) & 274 \\
\hline - Banks and financial institutions & 66 \\
\hline = Firms included in the sample & 208 \\
\hline Number of firm-year observations for 2005-2012 & 1664 \\
\hline - Observations with unavailable accounting data & 620 \\
\hline = Final number of observations & 1044 \\
\hline
\end{tabular}

Source: Author's projection 


\section{Findings and discussion}

Using a sample of 1044 Spanish non-financial, non-utility and profit-making firm-year observations for the period 2005-2012, this paper can document findings consistent with Filip and Raffournier (2012).

Consistent with the prediction, the results reveal a decrease in income smoothing in times of crisis. The results are robust also after alternative measures and test specifications.

Table no. 2 presents the results of the two income smoothing metrics used for the pooled sample. The results are also presented for each year for the period under examination (2005-2012).

IS 1 and IS 2 measures used for assessing the income smoothing behavior of firms, exhibit a similar time pattern like in Filip and Raffournier (2012). The lowest values for IS 1 is for the year 2012 (IS $1=0,495$ ) followed by year 2011 (IS $1=0,791$ ), known as years after the financial crisis. In regards of the values of IS 2, the lowest values are obtained for the year 2012 (IS $2=0,533$ ) followed by the year 2010 (IS $2=0,651$ ). In the years of the financial crisis the values for both measures used are higher than in the years after the financial crisis but not higher than the years before the financial crisis. In this respect, IS 1 decrease in the years of financial crisis compared with the years before financial crisis (for year 2008 - IS $1=1,197$ and for year $2009-$ IS $1=$ 1,142). Similar pattern can be observed for IS 2 (for year 2008 - IS $2=0,864$ and for year 2009 IS $2=0,691)$.

Twofold explanations can be given. First, as the exploration starts with year 2005 (the first year implementation of IFRS, where according to Capkun et al. (2011), earnings management can be more prominent) the subsequent decrease in income smoothing can be a result of previous extreme accruals reversals that has an impact on future earnings (Allen et al., 2013). Second, the financial crisis can impact negatively the income smoothing behavior of firms, causing a significant decrease. What is interesting to notice, is that last two years analyzed $(2011,2012)$ exhibit even more decreasing in both measures used for assessing income smoothing behavior.

Table no. 2

Results per year

\begin{tabular}{|c|c|c|c|}
\hline \multirow{2}{*}{ Year } & \multirow{2}{*}{} & \multicolumn{2}{|c|}{ Income Smoothing } \\
\cline { 3 - 4 } & & IS 1 & IS 2 \\
\hline Pool & 1044 & 1,117 & 0,801 \\
\hline 2005 & 146 & 1,655 & 0,869 \\
\hline 2006 & 131 & 1,674 & 0,947 \\
\hline 2007 & 127 & 1,677 & 0,919 \\
\hline 2008 & 136 & 1,197 & 0,864 \\
\hline 2009 & 135 & 1,142 & 0,691 \\
\hline 2010 & 134 & 0,814 & 0,651 \\
\hline 2011 & 128 & 0,791 & 0,714 \\
\hline 2012 & 107 & 0,495 & 0,533 \\
\hline \multicolumn{3}{|c}{ Source: Author's projection } \\
\hline
\end{tabular}

When testing for the significance of the differences obtained (using a similar method as Filip and Raffournier, 2012), the results were consistent with the conjecture that income smoothing decreases during financial crisis. The influence of financial crisis on income smoothing is also exhibit in the Annex no. 1. Average values of indicators for the pre-crisis (2005-2007) period, crisis-period (2008-2009) and post-crisis period (2010-2012) are reported in the Annex no. 1. In this respect, the income smoothing indicators (IS 1 and IS 2) decrease significantly in the crisis period. The decreasing trend can be notices also in the post-crisis period. Average values of IS 1 decreases from 1,665 in the pre-crisis period to 1,174 in the crisis period. Comparing the pre-crisis period with post-crisis period the decrease is even more significant (e.g. from 1,665 to 0,716). A similar 
pattern can be observed for the second measure used, that decreases from 0,911 in the pre-crisis period to 0,793 in the crisis period. This metrics also exhibit a significant decrease in the pre-crisis period compared with the post-crisis period (e.g. from 0,911 to 0,643 ).

\section{Conclusions, limitations and scope for future research}

Assessing the smoothing behavior of Spanish firms for the period 2005-2012, it can be noticed a significant decrease of both measures used in the period 2007-2009. In the light of the empirical evidence, the research hypotheses developed can be validated. Based on the fact that both the measures used for assessing income smoothing behavior decrease significantly after the financial crisis period also, another potential explanation for the results obtained can rely on the documented results obtained by Capkun et al. (2011) and Allen et al. (2013). Since this study introduced the year 2005 in the assessment, the decrease in the period 2007-2009 can be also interpreted as aggressive accruals reversals.

As main limitation, the manually collected data can introduce some potential bias. Also, based on the fact that cash flow from operation had to be calculated for the years 2005-2007 (no disclosure available) using the indirect method, other potential limitations can arise. Third, since this particular study is conducted at a country level, the external validity of the findings is questionable. Further research can enlarge the sample and can assess the smoothing behavior of firms at EU level, taking into account all firm-years observation until present time. The results presented are consisted with the results obtained by Filip and Raffournier (2012).

\section{References}

1. Ahmad-Zaluki N.A., Campbell K., Goodacre A., 2011. Earnings management in Malaysian IPOs: The East Asian crisis, ownership control, and post-IPO performance, The International Journal of Accounting, volume 46, pp. 111-137

2. Allen E., Larson C., Sloan R.G., 2013. Accrual Reversals, Earnings and Stock Returns, Journal of Accounting and Economics, volume 56, pp. 113-129

3. Ball R., Shivakumar L., 2005. Earnings quality in U.K. private firms: Comparative loss recognition timeliness, Journal of Accounting and Economics, volume 39, pp. 83-128

4. Barth M.E., Landsman W.R., Lang M.H., 2008. International accounting standards and accounting quality, Journal of Accounting Research, volume 46, pp. 467-498

5. Bhattacharya N., Black E.L., Christensen T.E., Larson C.R., 2003. Assessing the relative informativeness and permanence of pro forma earnings and GAAP operating earnings, Journal of Accounting and Economics, volume 36, pp. 285-319

6. Bradshaw M.T., Sloan R.G., 2002. GAAP versus the street: An empirical assessment of two alternative definitions of earnings, Journal of Accounting Research, volume 40, pp. 41-66

7. Biedleman C., 1973. Income smoothing: The role of management, The Accounting Review, volume 48, number 4, pp. 653-667

8. Buckmaster D.A., 2001. Development of the income smoothing literature 1893-1998, 1st ed. The Netherlands, Elsevier Science Ltd.

9. Capkun V., Cazavan-Jeny A., Jeanjean T., Weiss L.A., 2011. Setting the bar: Earningsmanagement during a change in accounting standards, Working paper available on www.ssrn.com, last consulted: 15.09.2013

10. Cohen D.A., Zarowin P., 2010. Accrual-based and real earnings management activities around seasoned equity offerings, Journal of Accounting and Economics, volume 50, pp. 2-19

11. Choi Y.S., Lin S., Walker M., Young S., 2005. Voluntary disclosure of alternative earnings per share numbers, Working paper, Lancaster University 
12. Daske H., Gebhardt G., McLeay S., 2006. The Distribution of Earnings Relative to targets inthe European Union, Accounting and Business Research, volume 36, issue 3, pp. 137-168

13. DeAngelo L.E., 1988. Managerial competition, information costs, and corporate governance: The use of accounting performance measures in proxy contests, Journal of Accounting and Economics, volume 10, pp. 3-36

14. Dechow P.M., 1994. Accounting earnings and cash flows as measures of firm performance: the role of accounting accruals, Journal of Accounting and Economics, volume 18, pp. 3-42

15. Dechow P., Sloan R., 1991. Executive incentives and the horizon problem: An empirical investigation, Journal of Accounting and Economics, volume 14, pp. 51-89

16. DeFond, M., Park C.W., 1997. Do managers smooth income in anticipation of futureearnings?, Journal of Accounting and Economics, volume 23, pp. 115-139

17. Dye R.A., 1988. Earnings management in an overlapping generations model, Journal of Accounting Research, volume 26, number 2, pp. 195-235

18. Eckel N., 1981. The income smoothing hypothesis revisited, Abacus, volume 17, issue 1, pp. $28-40$

19. Filip A., Raffournier B., 2012. The impact of the 2008-2009 financial crisis on earnings management: the European evidence, Working paper

20. Fudenberg D., Tirole J., 1995. A theory of income and dividend smoothing based on incumbency rents, Journal of Political Economy, volume 103, pp. 75-93

21. Graham J.R., Harvey C.R., Rajgopal S., 2005. The economic implications of corporate financial reporting, Journal of Accounting and Economics, volume 40, pp. 3-73

22. Gordon M.J., 1964. Postulates, principles and research in accounting, The Accounting Review, volume 39, pp. 251-263

23. Han S., Kang T, Salter S., Yoo Y., 2010. A Cross-Country Study on the Effects of National Culture on Earnings Management, Journal of International Business Studies, volume 41, issue 1, pp. 123-141

24. Healy P., 1985. The impact of bonus schemes on the selection of accounting principles, Journal of Accounting and Economics, volume 7, pp. 85-107

25. Healy P.M., Wahlen J.M., 1999. A review of the earnings management literature and its implications for standard setting, Accounting Horizons, volume 13, number 4, pp. 365-384

26. Herrman D., Inoue T., 1996. Income smoothing and incentives by operating condition: an empirical test using depreciation changes in Japan, Journal of International Accounting, Auditing and Taxation, volume 5, issue 2, pp. 161-178

27. Holthausen R.W., Larker D.F., Sloan R.G., 1995. Annual bonus schemes and the manipulation of earnings, Journal of Accounting and Economics, volume 19, pp. 29-74

28. Huang P., Zhang Y., Deis D.R., Moffitt J.S., 2009. Do artificial income smoothing and real income smoothing contribute to firm value equivalently?, Journal of Banking and Finance, volume 33 , issue 2, pp. 224-233

29. Imhoff E.A., 1977. Income smoothing - a case for doubt, The Accounting Journal, volume 1, number 1, pp. 85-100

30. Koch B.S., 1981. Income smoothing: an experiment, The Accounting Review, volume 56, number 3, pp. 574-586

31. La Porta R., Lopez-de-Silanes F., Shleifer A., 1998. Law and finance, Journal of Political Economy, volume 106, pp. 1113-1155

32. Lambert R., 1984. Income smoothing as rational equilibrium behavior, The Accounting Review, volume 59, number 4, pp. 604-618

33. Lang M., Raedy J.S., Wilson W., 2006. Earnings management and cross listing: Are reconciled earnings comparable to US earnings?, Journal of Accounting and Economics, volume 42 , pp. $255-283$ 
34. LaFond, R., Lang M.H., Skaife H.A., 2007. Earnings smoothing, governance, and liquidity: International evidence. Working paper, Barclay's Global Investor, University of North Carolina and University of Wisconsin, available at www.ssrn.com, last consulted: 10.09.2013

35. Leuz C., Nanda D., Wysocki P.D., 2003. Earnings management and investor protection: An international comparison, Journal of Financial Economics, volume 69, pp. 505-527

36. Levitt A., 1998. The importance of high quality accounting standards, Accounting Horizons, volume 12, number 2, pp. 79-82

37. Lougee B., Marquardt C., 2004. Earnings quality and strategic disclosure: An empirical examination of 'pro forma' earnings. The Accounting Review, volume 79, pp. 769-795

38. Michelson S.E., Jordan-Wagner J., Wootton C.W., 2000. The relationship between the smoothing of reported income and risk-adjusted returns, Journal of Economics and Finance, volume 24, issue 2, pp. 141-159

39. Michelson S.E., Jordan-Wagner J., Wootton C.W., 1995. A market based analysis of income smoothing, Journal of Business Finance and Accounting, volume 22, pp. 1179-1193

40. Moses O.D., 1987. Income smoothing and incentives: Empirical tests using accounting changes, The Accounting Review, volume 62, pp. 358-377

41. Navarro-Garcia J., Bastida F., 2010. An Empirical Inight on Spanish Listed Companies Perceptions of International Reporting Standards, Journal of International Accounting, Auditing and Taxation, volume 19, pp. 110-120

42. Ronen J., Sadan S., 1975. Classificatory smoothing: alternative income methods, Journal of Accounting Research, volume 13, issue 1, pp. 133-149

43. Shaw K.W., 2003. Corporate disclosure quality, earnings smoothing, and earnings' timeliness, Journal of Business Research, volume 56, pp.1043-1050

44. Strobl G., 2013. Earnings Manipulation and the Cost of Capital, Journal of Accounting Research, volume 51, issue 2, pp. 449-473

45. Trueman B., Titman S., 1988. An explanation for accounting income smoothing, Journal of Accounting Research, volume 26, pp. 127-139

46. Wang Z., Williams T., 1994. Accounting income smoothing and stockholder wealth, Journal of Applied Business Research, volume 10, issue 3, pp. 96-104

47. Watts R., Zimmerman J., 1990. Positive accounting theory: a ten year perspective, The Accounting Review, volume 65, number 1, pp. 131-156

48. Watts R.L., Zimmerman J.L., 1978. Towards a positive theory of the determination of accounting standards, The Accounting Review, volume 53, pp. 112-134

49. Zeghal D., Chtourou S., Sellami Y., 2011. An Analysis of the Effect of Mandatory Adoption of IAS/IFRS on Earnings Management, Journal of International Accounting, Auditing and Taxation, volume 20, pp. 61-72

The influence of financial crisis on income smoothing

Annex no. 1

\begin{tabular}{|c|c|c|c|}
\hline \multirow{2}{*}{ Period } & N & \multicolumn{2}{|c|}{ Income Smoothing } \\
\cline { 3 - 4 } & & IS 1 & IS 2 \\
\hline Pool & 1044 & 1,117 & 0,801 \\
\hline $2005-2007$ & 404 & 1,665 & 0,911 \\
\hline $2008-2009$ & 271 & 1,174 & 0,793 \\
\hline $2010-2012$ & 369 & 0,716 & 0,643 \\
\hline
\end{tabular}

Source: Author's projection 